Article

\title{
Compaction Procedures and Associated Environmental Impacts Analysis for Application of Steel Slag in Road Base Layer
}

\author{
Bo Gao $^{1}$, Chao Yang ${ }^{1}\left(\mathbb{D}\right.$, Yingxue Zou ${ }^{1}$, Fusong Wang ${ }^{1, *}\left(\mathbb{C}\right.$, Xiaojun Zhou $^{2}$, Diego Maria Barbieri ${ }^{3}$ \\ and Shaopeng $\mathrm{Wu}^{1}$ \\ 1 State Key Laboratory of Silicate Materials for Architectures, Wuhan University of Technology, \\ Wuhan 430070, China; gaobomax1017@163.com (B.G.); hbyangc@whut.edu.cn (C.Y.); \\ zouyingxue@whut.edu.cn (Y.Z.); wusp@whut.edu.cn (S.W.) \\ 2 State Key Laboratory of High-Performance Civil Engineering Materials, Sobute New Materials Co., Ltd., \\ Nanjing 211103, China; zhouxiaojun@cnjsjk.cn \\ 3 Department of Civil and Environmental Engineering, Norwegian University of Science and Technology, \\ 7491 Trondheim, Norway; diego.barbieri@ntnu.no \\ * Correspondence: wangfs@whut.edu.cn
}

check for updates

Citation: Gao, B.; Yang, C.; Zou, Y.; Wang, F.; Zhou, X.; Barbieri, D.M.; Wu, S. Compaction Procedures and Associated Environmental Impacts Analysis for Application of Steel Slag in Road Base Layer. Sustainability 2021, 13, 4396. https://doi.org/ $10.3390 /$ su13084396

Academic Editors: Dimitrios G. Goulias and Marco Bassani

Received: 25 March 2021

Accepted: 13 April 2021

Published: 15 April 2021

Publisher's Note: MDPI stays neutral with regard to jurisdictional claims in published maps and institutional affiliations.

Copyright: (c) 2021 by the authors. Licensee MDPI, Basel, Switzerland. This article is an open access article distributed under the terms and conditions of the Creative Commons Attribution (CC BY) license (https:/ / creativecommons.org/licenses/by/ $4.0 /)$.

\begin{abstract}
In recent years, recycling steel slag is receiving growing interest in the road base layer construction field due to its role in alleviating land occupation and resource shortages. However, the mixture compaction and its environmental impact on practical construction sites remain unclear, which may hinder the application of steel slags in road layers. This study investigates the pavement construction of the 'Baotou-Maoming' motorway, located in Inner Mongolia, China, analyzing the compaction procedures and assessing the environmental impacts caused by the road base layer containing steel slag. Firstly, mechanical properties and texture appearances of the steel slag aggregates are characterized. Afterwards, the comparative assessments for steel slag and andesite layers compaction are quantified from equivalent $\mathrm{CO}_{2}$ emission and energy consumption aspects, respectively. The results show that the steel slag has a better surface texture than the natural aggregates; physical properties including compactness, flatness and compressive strength comply with the requirements for applying steel slag to a hydraulically bound mixture. Compared to the base layer using andesite aggregates, the compaction vibration period of the course containing steel slags should be reduced to achieve a proper density due to the "hard-to-hard" effect that occurs between the adjacent steel slag particles. Consequently, the additional energy and the equivalent $\mathrm{CO}_{2}$ are generated at $2.67 \mathrm{MJ} / \mathrm{m}^{3}$ and $0.20 \mathrm{~kg} / \mathrm{m}^{3}$, respectively.
\end{abstract}

Keywords: steel slag; road base layer; compaction procedure; energy consumption; carbon dioxide emission

\section{Introduction}

Road networks have been rapidly developing in recent decades, which is strictly linked to modernization and urbanization. The United States Department of Transportation announced that the national highway system was composed of over 164,000 miles of highway in 2011 [1], while the length increased to 223,257 miles in 2017 [2]. At the end of 2018, the total length of national highways in China reached 4.85 million kilometers [3], reaching 5.01 million kilometers in 2019 [4]. In many studies, the rapid expansion and improvement of new road constructions can be seen, especially in developing countries [5]. Nevertheless, the sustainability of road construction and development is increasingly questioned due to various environmental issues, such as the large consumptions of natural aggregate resources.

With the exploration of solid waste recycling, steel slag has become a potential material to be increasingly developed and used as a manufactured aggregate for civil engineering applications [6]. Generally, steel slag is a by-product of the steelmaking industry. In the 
steelmaking furnace, various raw materials (iron ore, steel scrap, pig iron, limestone and so forth) are refined at a high temperature, and the refined mixture is divided into two incompatible liquid phases by controlling the temperature. One part is molten steel, and the other part is steel slag. Currently, there are five different types of steel slags generated by different sources: blast furnace slag, basic oxygen furnace slag, electric arc furnace slag, ladle furnace slag and stainless steel slag [7].

Previously, steel slag was stacked on abandoned ground for long periods of time [8]. Since, several researchers have found that steel slag powder can be used as filler to promote the mechanical properties of cement concrete [9]. Studies have increasingly investigated the alternative utilization of steel slags in road construction. In recent years, concerns about the environmental impacts of utilizing steel slags in road construction have been constantly raised. The primary benefit of steel slag recycling is to reduce the land used by steel waste stockpiling; moreover, the application of manufactured alternatives greatly relieves the shortage of natural aggregates worldwide [10]. According to an investigation on natural aggregate extraction, the energy consumption for specific aggregate production ranges from 25.2 to $32.2 \mathrm{MJ} /$ ton [11]. Furthermore, numerous explosives and chemical emulsions are employed during aggregate extraction processes, generating massive amounts of air pollutants and heavy metals. On the contrary, steel slag is a by-product of the steel making industry, and so theoretically brings about limited environmental burdens during its production process.

Considerable concerns have been raised in road construction studies regarding the release of potentially hazardous components by steel slag aggregates. Ivana et al. analyzed the potential adverse impacts of steel slag leachate. The results indicated that the leachates from two tested steel slags showed weak alkalinity, and the concentrations of toxic elements (heavy metals) are far below the limit, posing little risk to the ecological environment [12]. Moustakas et al. investigated the leaching impacts of air-cooled and water-cooled slags. The results considered the European official decision (2003/33/EC) and leaching procedures test, and confirmed the safety of slag utilization [13]. Sasmita et al. collected slag leachates from three steelmaking manufacturers and assessed their contents of heavy metals. The results showed that toxic elements (As, Cd, Se and V) had not been leached, and other heavy metals were below the warning value [14]. Xie et al. evaluated the utilization possibility of steel slag from both laboratory and in-place perspectives. The results showed that the leachate fulfilled most of the global environmental laws and regulations [15]. Hence, steel slag can be considered to be a sustainable material for recycling in road construction, in terms of the economy and environmental protection.

A report from the European Slag Association showed that $43 \%$ of steel slag arisings were employed in road construction in 2012 [16]. On the contrary, notwithstanding the meaningful increase in the generation of steel slag in China, 29.5\% of steel slag is ineffectively utilized, over 300 million tons of which cannot be reasonably treated and recycled [8]. Currently, most studies focus on the performance effect of employing steel slag in pavement constructions and on the overall environmental impacts. Monshi et al. proved that steel slag concrete had better compressive strength than original Portland cement concrete [17]. Maslehuddin et al. proved that some physical and mechanical properties (i.e., resistance to reinforcement corrosion and compressive strength) of steel slag concrete were better than limestone concrete [18]. Srinivasa et al. found an improvement in cementing properties when using quenched slag products in hydraulically bound mixtures [19]. Altun et al. reported that applying steel slag as an aggregate can obtain an acceptable physical and mechanical performance [20]. The existing literature indicates that steel slag cement mixtures can be well applied to the road base layer.

From the perspective of Life Cycle Assessments (LCA), substantial environmental benefits can be obtained by applying steel slag aggregate [21]. Saade et al. investigated whether using steel slag can significantly contribute to the reduction of Greenhouse Gas (GHG) emissions, global warming and terrestrial ecotoxicity [22]. Pasetto conducted the case study and employed PaLATE (a widely used LCA tool) to compare the feasibility of 
steel slag and natural mineral aggregates in asphalt pavement construction, stating that approximately $39.77 \mathrm{TJ}$ of energy and 2653 tons of $\mathrm{CO}_{2}$ can be reduced during the material production process [23]. Václavík et al. replaced natural aggregates with steel slag in cement concrete and investigated associated environmental impacts using an LCA. The results showed that steel slag aggregate can diminish 7\% of environmental burdens [24]. Anastasiou et al. considered the sustainability of utilizing industrial by-products (fly ash and steel slag) in cement mixtures. The results found that cement clinker content is critical for GHG emissions, and the transport distances of steel slag aggregate could strikingly affect the environmental burdens in the material production stage [25].

The majority of research explores the potentials of steel slag in laboratories, while the specific construction procedures related to practical pavement engineering are seldom researched and reported, which may hinder the application of steel slag in pavement construction. To address the research gap, this study has investigated a stretch of motorway located in Inner Mongolia, China. The surface's micro-texture and the composition of the manufactured aggregates were analyzed in the laboratory before application in the field. The effect on basic road performance was analyzed for the different compaction procedures of a hydraulically bound mixture containing steel slag aggregate, compared with a reference material andesite, while the base course compaction procedure was thoroughly investigated in the field by means of three types of compaction plants. Eventually, the associated equivalent $\mathrm{CO}_{2}$ emissions and energy consumptions were analyzed to assess the overall environmental impacts when steel slag was applied into the road base layer.

\section{Materials and Methods for the Case Study}

This study has considered the construction of a hydraulically bound mixture for a road base layer along the "Baotou-Maoming" motorway located in Inner Mongolia, China. The base course was designed with a width of $7 \mathrm{~m}$ and a thickness of $20 \mathrm{~cm}$.

\subsection{Physical Properties of Steel Slag and Andesite}

The steel slags, obtained from Lucheng and supplied by the Baotou City Steel Slag Road Performance and Engineering Application Research Center, underwent a three-stage process to make them into usable manufactured aggregates: initially, the tailings (blast furnace slags) generated by the steel industry were placed into a hot furnace and cooled down; afterwards, the steel tailings were aged by climate conditions, aiming to decrease the expansion and shrinkage effects; then, the stable slags were crushed, and sieved for appropriate sizes according to the actual requirements.

Lucheng steel slags and andesite were used in the hydraulically bound mixture as coarse and fine aggregates (the size designating the limit between coarse and fine dimensions was considered equal to $4.75 \mathrm{~mm}$ ), respectively [26]. For comparison, the study also investigated a traditional base layer which only comprised of andesite aggregates for the hydraulically bound mixture. Portland cement with a compressive strength grade of 32.5 MPa was employed as binder (Table 1). The physical and mechanical properties of the steel slags were investigated according to the Chinese standard of Testing Methods of Aggregate for Highway Engineering (JTG E42-2005) [27] and displayed in Table 2. In addition, the content of free calcium oxide ( $\mathrm{f}-\mathrm{CaO})$, usually regarded as a major issue due to the phenomenon of swelling in water [28,29], is listed in Table 2, which is below the suggested limit [30]. 
Table 1. Fundamental properties of the cement used in the road base layer.

\begin{tabular}{|c|c|c|c|c|}
\hline Property & Characteristic & Result & Requirement & Standard \\
\hline Fineness & $80 \mu \mathrm{m}(\%)$ & 1.0 & $<10$ & GB/T1345-2005 \\
\hline \multirow[b]{2}{*}{ Setting time } & Initial (min) & 259 & $\geq 180$ & \multirow[b]{2}{*}{ GB/T1346-2011 } \\
\hline & Final (min) & 420 & $\begin{array}{l}\geq 360 \\
\leq 600\end{array}$ & \\
\hline \multirow{2}{*}{ Flexural strength } & 3d (MPa) & 4.4 & $\geq 2.5$ & \multirow{4}{*}{ GBT17671-1999 } \\
\hline & 28d (MPa) & 7.5 & $\geq 5.5$ & \\
\hline \multirow{2}{*}{$\begin{array}{l}\text { Compressive } \\
\text { strength }\end{array}$} & 3d (MPa) & 18.5 & $\geq 10.0$ & \\
\hline & 28d (MPa) & 38.4 & $\geq 32.5$ & \\
\hline \multirow{4}{*}{$\begin{array}{l}\text { Composition } \\
\text { content }\end{array}$} & $\mathrm{SO}_{3}(\%)$ & 2.34 & $\leq 4.0$ & \multirow{4}{*}{ GB/T176-2008 } \\
\hline & $\mathrm{MgO}(\%)$ & 4.04 & $\leq 6.0$ & \\
\hline & $\mathrm{Cl}^{-}(\%)$ & 0.01 & $\leq 0.06$ & \\
\hline & Ignition loss (\%) & 1.15 & $\leq 5.0$ & \\
\hline
\end{tabular}

Table 2. Fundamental properties of Lucheng steel slag.

\begin{tabular}{ccccc}
\hline Property & Size & Result & Requirement & Standard \\
\hline Crushing value (\%) & - & 10.3 & $\leq 26$ & T0316 \\
\hline $\begin{array}{c}\text { Los Angeles } \\
\text { abrasion value (\%) }\end{array}$ & - & 8.5 & $\leq 28$ & T0317 \\
\hline $\begin{array}{c}\text { Flake particles } \\
\text { content }(\%)\end{array}$ & $4.75-9.5 \mathrm{~mm}$ & 10.1 & $\leq 12$ & T0312 \\
\hline $\begin{array}{c}\text { Weak particles } \\
\text { content }(\%)\end{array}$ & $-9.5 \mathrm{~mm}$ & 6.7 & $\leq 12$ & T0320 \\
\hline f-CaO content (\%) & $10-16 \mathrm{~mm}$ & 0.2 & $\leq 3$ & YB140-2009 \\
\hline
\end{tabular}

The physical properties of the aggregates are closely related to the load capacity of the hydraulically bound mixture, as well as to the adhesion with the cement binder [31]. The surfaces of both the Lucheng steel slag and andesite were investigated by means of an Aggregates Image Measurement System (AIMS) device (Figure 1). The Texture Index (TI) is commonly used for quantifying the aggregate's surface texture. TI values, obtained as reported in Equation (1), range from 0 to 1000: a bigger TI indicates a rougher surface, leading to a higher shear resistance and load capacity of the mixture [32,33]. Twenty aggregates with particle sizes comprised between $10 \mathrm{~mm}$ and $16 \mathrm{~mm}$ were investigated and given a TI value.

$$
T I=\frac{1}{3 n} \sum_{i=1}^{3} \sum_{j=1}^{N}\left(D_{i, j}(x, y)\right)^{2},
$$

where $n$ is the decomposition level during measurement, $N$ is the total number of coefficients in the detected image, the $i$ value is 1,2 or 3 based on the image analysis dimension (horizontal, vertical, and diagonal), the $j$ value corresponds to the wavelet coefficient index, $D$ is the compiled decomposition function, and $x$ and $y$ locate the coefficients in a transformed domain. 


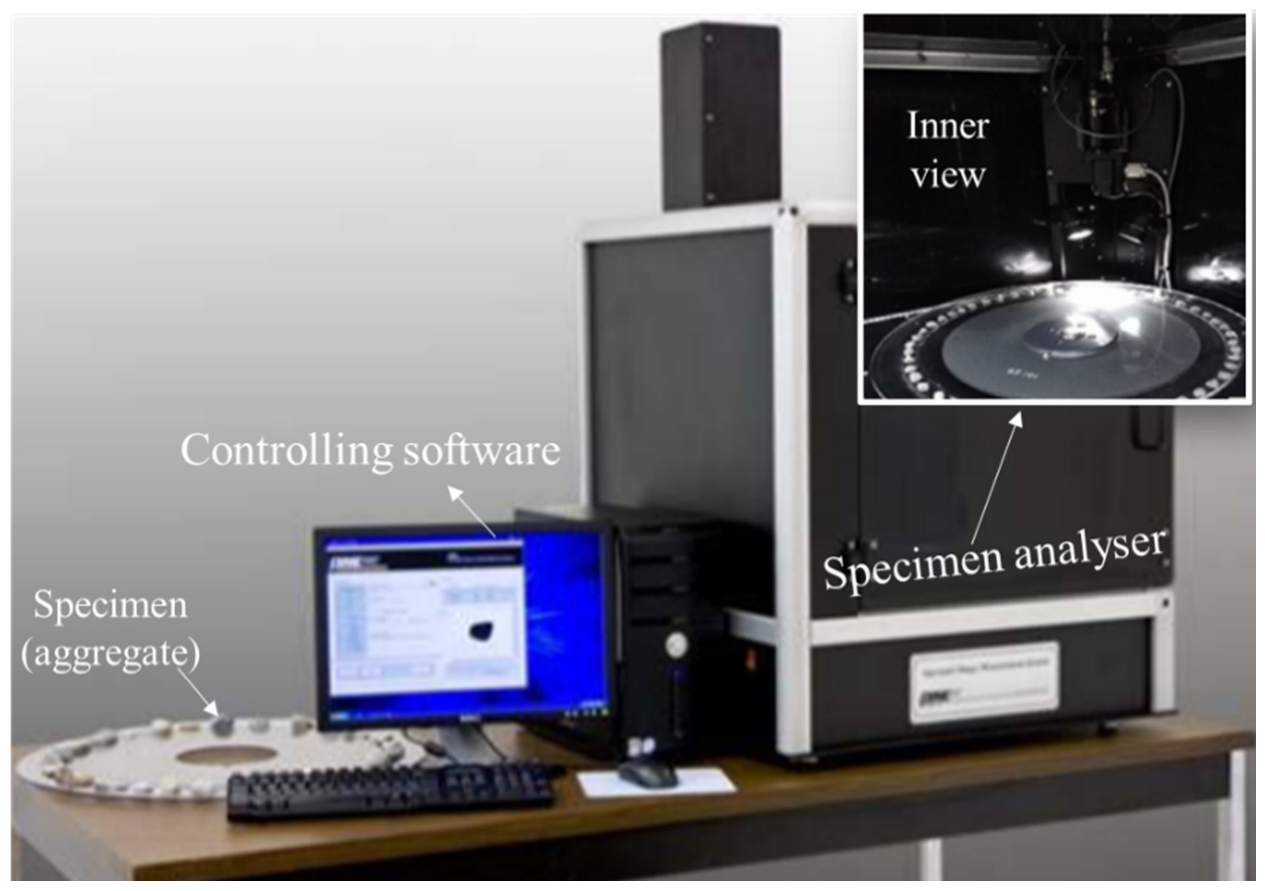

Figure 1. Aggregates Image Measurement System (AIMS) device.

Four different TI ranges were used to describe the surface roughness, namely 0-200 (low), 200-500 (moderate), 500-750 (high) and 750-1000 (extreme). Figure 2 shows the cumulative TI percentage of Lucheng steel slag and andesite: most of the natural aggregates belong to a moderate level, while the largest part of the manufactured steel slag aggregates lies within a high level. The average TI values for Lucheng steel slag and andesite were 566.8 and 437.5, respectively. A greater TI value of an aggregate can obtain a stronger load capacity of the hydraulically bound mixture. Hence, Lucheng steel slag offers a better surface texture for cement workability.

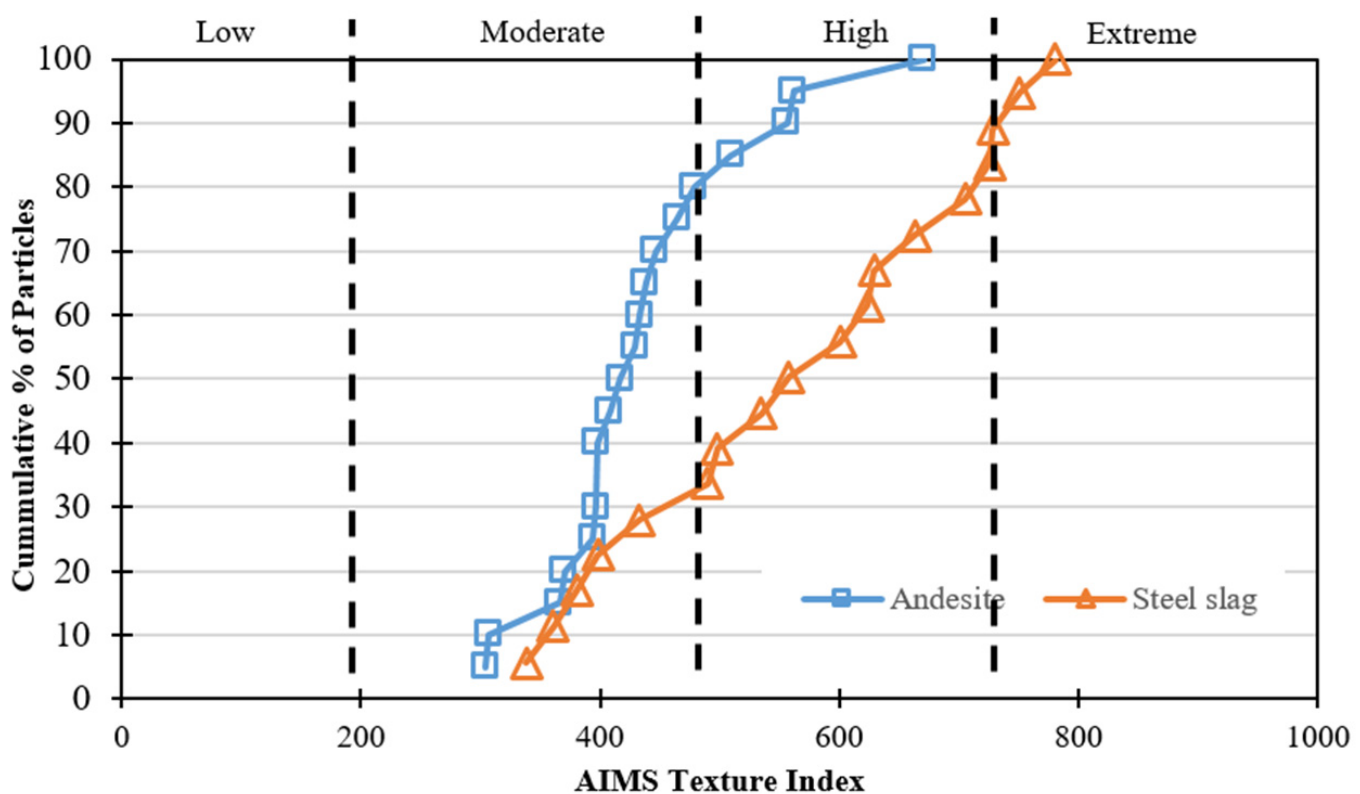

Figure 2. Texture Index (TI) of Lucheng steel slag aggregate and andesite aggregate.

Furthermore, this study employed a Mean Free Path-3 Dimensions-Scanning Atomic Force Probe (MFP-3D-SA) to investigate the microscopic characteristics of the aggregate 
interface. The fractal dimension was utilized to describe the irregularity of each point on the scanned surfaces, and the logarithmic curve of the incremental variable was adopted to analyze the slope and the shape of the aggregate interface. The width and depth of the image was $20 \mu \mathrm{m}$ and the height was $2.5 \mu \mathrm{m}$. Figure 3a,b show the 3D microscopic texture of Lucheng steel slag and andesite, respectively. The obvious differences in structure and microscopic characteristics illustrated that the lighter color which appeared in Figure 3a accounts for a higher percentage, and its emulated structure also presents a greater angularity than Figure 3b. Therefore, compared to manufactured aggregate, the surface texture of natural aggregate is more regular, indicating that the selected steel slag aggregate has better surface characteristics to prepare a hydraulically bound mixture.

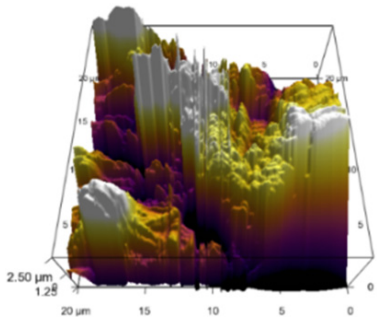

(a)

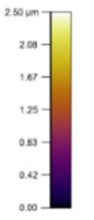

Figure 3. 3D microscopic texture interface for steel slag (a) and andesite (b).

\subsection{Study Methods}

Figure 4 illustrates the research diagram of this study. The surface textures of both of the base layers containing manufactured aggregates and natural aggregates were initially analyzed by means of an Aggregates Image Measurement System (AIMS) and a Mean Free Path-3 Dimensions-Scanning Atomic Force Probe (MFP-3D-SA). Successively, the following in-service properties were assessed: surface flatness, layer compaction and compressive strength of hydraulically bound mixture specimens. Eventually, the research quantified the equivalent $\mathrm{CO}_{2}$ emissions and the energy consumption related to the compaction operations.

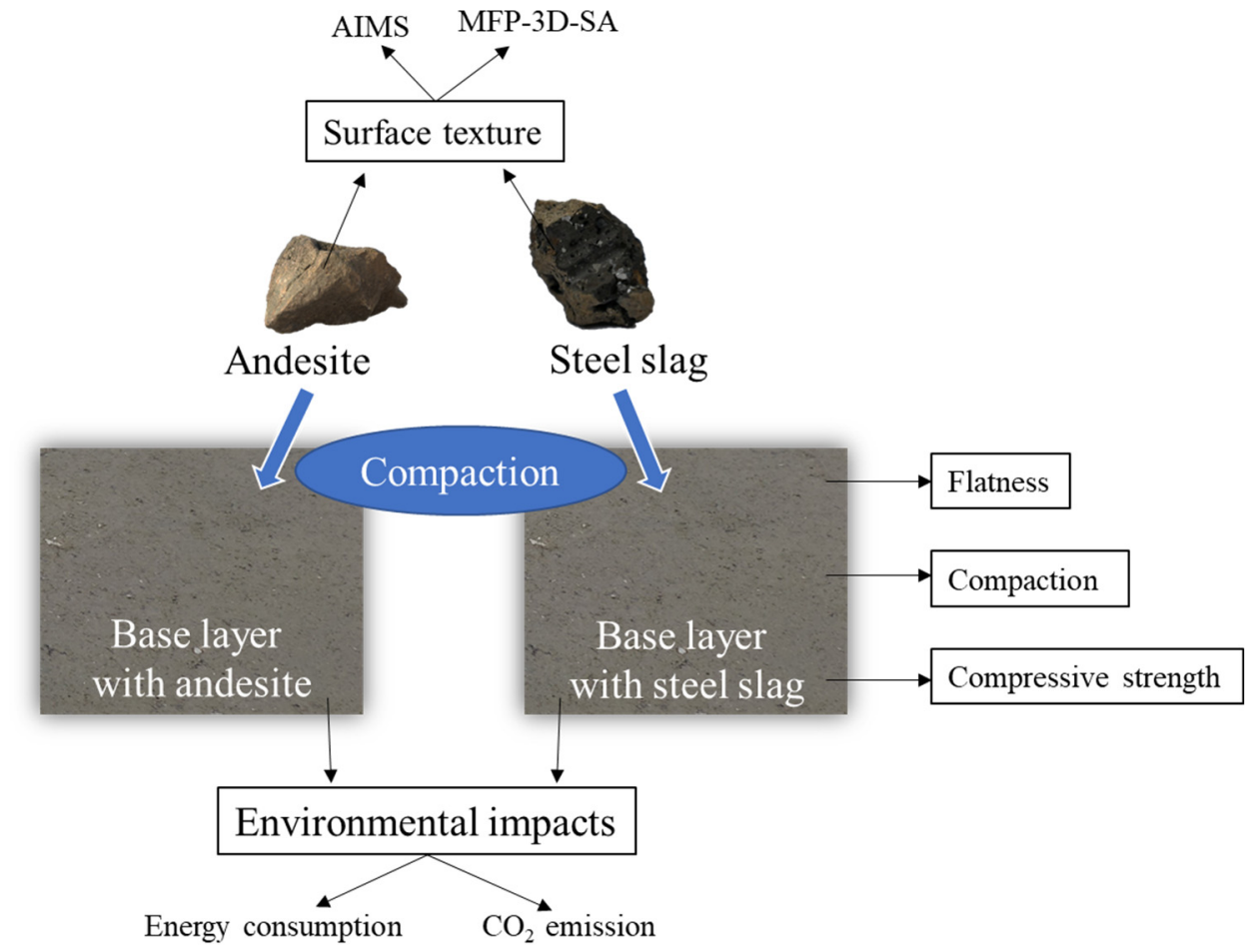

Figure 4. Research diagram of the hydraulically bound mixture for the road base layer. 


\section{Results and Discussion}

\subsection{Mechanical Properties of Base Layer}

Steel slag was used for the coarse aggregate fractions (size bigger than $4.75 \mathrm{~mm}$ ) and andesite for the fine aggregate fractions during the production of the hydraulically bound mixture. Table 3 presents the gradation design of the aggregates. The percentage of added cement was $5 \%$ by mass, and water content applied here was $4.6 \%$.

Table 3. Blending ratio for hydraulically bound mixture containing steel slag.

\begin{tabular}{cccccc}
\hline Material & \multicolumn{4}{c}{ Steel Slag } & Andesite \\
\hline Size $(\mathrm{mm})$ & $19-26.5$ & $6-19$ & $9.5-16$ & $4.75-9.5$ & $0-4.75$ \\
\hline Mass ratio (\%) & 13 & 16 & 18 & 22 & 31 \\
\hline
\end{tabular}

\subsubsection{Optimization of Compaction Procedure}

In this investigated case, three different types of compactors were used in the field for the base layer containing steel slags: Single Steel Wheel Roller (SSWR), Double Steel Wheel Roller (DSWR) and Pneumatic Tired Roller (PTR). Table 4 presents the specifications of the used compactors.

Table 4. Roller compactors used for the base layer.

\begin{tabular}{ccccc}
\hline Compactor & \multicolumn{2}{c}{ SSWR } & DSWR & PTR \\
\hline Wheel Type & SS225HD-2 & CLG 620H & KP306H & BOMAG203 \\
\hline Model & $32 / 28$ & $32 / 28$ & Rubber \\
\hline $\begin{array}{c}\text { Vibration } \\
\text { frequency, } \\
\text { max-min (Hz) }\end{array}$ & $415 / 285$ & $400 / 210$ & $/$ & $50 / 40$ \\
\hline $\begin{array}{c}\text { Vibration force, } \\
\text { max-min (kN) }\end{array}$ & $1.98 / 0.99$ & $1.90 / 1.00$ & $/$ & $0.69 / 0.29$ \\
\hline $\begin{array}{c}\text { Amplitude, } \\
\text { max-min (mm) }\end{array}$ & 140 & 132 & 140 & $126 / 84$ \\
\hline Power (kW) & & & 100 \\
\hline
\end{tabular}

The density achieved by each compaction procedure was evaluated using sand ( $\phi 15 \mathrm{~mm}$, loose density $1.38 \mathrm{~g} / \mathrm{cm}^{3}$ ) according to JTGE60-2008 [34]. The first investigated compaction procedure (C1) was conducted on andesite aggregates, composed of three vibration cycles (weak, strong, weak) for a total length of $60 \mathrm{~m}$ back and forth performed by a SSWR; successively, cycles two and one were accomplished by PTR and DSWR (static mode), respectively. After this compaction procedure, we measured the compactness (K) in two different locations with the maximum densities at $93.0 \%$ and $96.2 \%$. These results did not fulfil the practical requirements $(98.0 \%)$ based on the code of JTGE60-2008 [34].

Specifically, under the strong vibration, the surface of the steel slag mixture underwent deformation, meanwhile, under high frequency vibration, the "hard-to-hard" effect occurred between the adjacent steel slag particles, resulting in the loosening of the compacted mixture. The surface containing hard steel slag particles made the compaction process more sensitive than andesite. Hence, the compaction procedure (C1) could obtain a good compaction for andesite, but failed to achieve the required effects for steel slag. Figure 5 shows the "hard-to-hard" phenomenon for steel slag. 


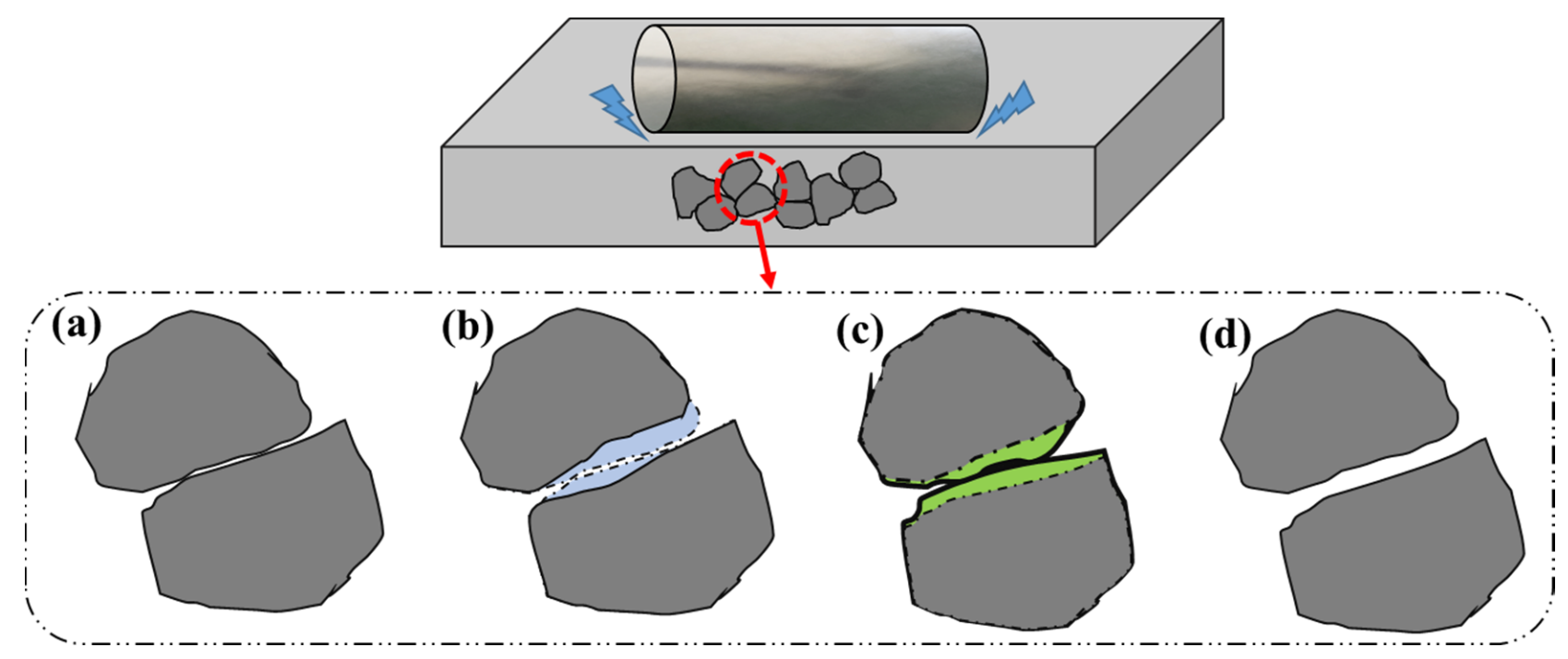

Figure 5. Steel slag "hard-to-hard" effect in compaction. The particles are initially relatively close to each other (a), deformation takes place under external strong vibration (b) and an elastic recovery expansion occurs successively (c). Eventually, the displacement of the particles results in a macroscopic decrease in density (d).

Based on the results obtained for the first compaction procedure, an optimized compaction procedure (C2) was proposed to alleviate the "hard-to-hard" effect. The operations were performed according to the following sequence: one SSWR cycle applying static pressure forth and strong vibration back; then, three SSWR cycles (static pressure) and two PTR cycles; eventually, one more SSWR cycle (static pressure). Following this procedure, the average compactness achieved $95.8 \%$. Although the code requirements were not met again, the higher values proved the beneficial effect generated by the weaker vibration.

Eventually, a third compaction procedure (C3) was investigated to increase the base layer density: one cycle with a SSWR (static pressure) plus three weak cycles with a SSWR (vibration); then, four cycles with a PTR; finally, one cycle completed with a DSWR (static pressure). The compactness values of $\mathrm{C} 3$ measured in three different locations (L1, L2, L3) were now equal to $97.8 \%, 98.8 \%$ and $99.1 \%$, respectively (Table 5). The average value was $98.6 \%$, which lies within the code threshold. The surfaces of the base layer compacted according to the three procedures $(\mathrm{C1}, \mathrm{C} 2, \mathrm{C} 3)$ are displayed in Figure 6 . The detrimental effect generated by the weak and the strong vibration is clearly visible in terms of loose surface; on the other hand, a proper density was achieved due to reduced vibration frequency and an increased number of cycles with static pressure.

Table 5. Compactness values for the final compaction procedure (C3) in three different locations.

\begin{tabular}{|c|c|c|c|c|}
\hline Location & $\begin{array}{c}\text { Wet Density } \\
\rho\left(\mathrm{g} / \mathrm{cm}^{3}\right)\end{array}$ & $\begin{array}{c}\text { Moisture } \\
\text { Content (\%) }\end{array}$ & $\begin{array}{c}\text { Dry Density } \\
\rho_{\mathrm{d}}\left(\mathrm{g} / \mathrm{cm}^{3}\right)\end{array}$ & $\begin{array}{c}\text { Compactness } \\
\text { K }\end{array}$ \\
\hline L1 & 2.875 & \multirow{3}{*}{5.5} & 2.725 & 97.8 \\
\hline L2 & 2.904 & & 2.753 & 98.8 \\
\hline L3 & 2.914 & & 2.762 & 99.1 \\
\hline
\end{tabular}




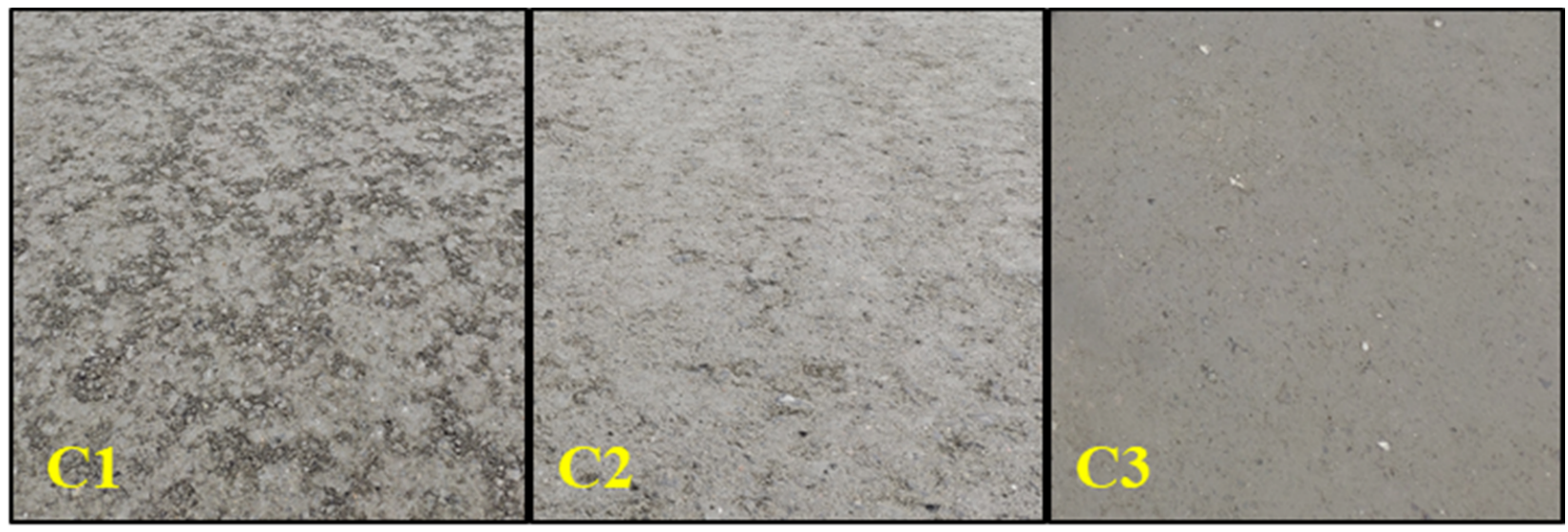

Figure 6. Surface of base layer compacted according to the C1-C3.

\subsubsection{Surface Flatness}

The flatness $(\sigma)$ of the base layer was analyzed after compaction by means of a Continuous Flatness Meter (CFM). The device wheel was equipped to measure the surface flatness for all of the test sections [35]. The device automatically recorded the vertical displacement deviations every $10 \mathrm{~cm}$ (unit measurement interval), and the final flatness index was evaluated every $100 \mathrm{~m}$ (Equation (2)). The CFM was towed for the entire base layer length $(500 \mathrm{~m})$ at the speed $(\mathrm{V})$ of $6.8 \mathrm{~km} / \mathrm{h}$.

$$
\sigma_{i}=\sqrt{\frac{\sum d_{i}^{2}-\left(\sum d_{i}\right)^{2} / N}{N-1}}
$$

where $\sigma_{i}$ is the standard deviation of flatness for $100 \mathrm{~m}(\mathrm{~mm}), d_{i}$ represents the displacement deviation for the unit measurement interval $(\mathrm{mm})$, and $N$ is the total number of recorded data.

The flatness $(\sigma)$ of all of the five test sections exceeded $1.2 \mathrm{~mm}$, and the average value was $1.3 \mathrm{~mm}$ (Figure 7); therefore, the standard requirements were fulfilled [36].

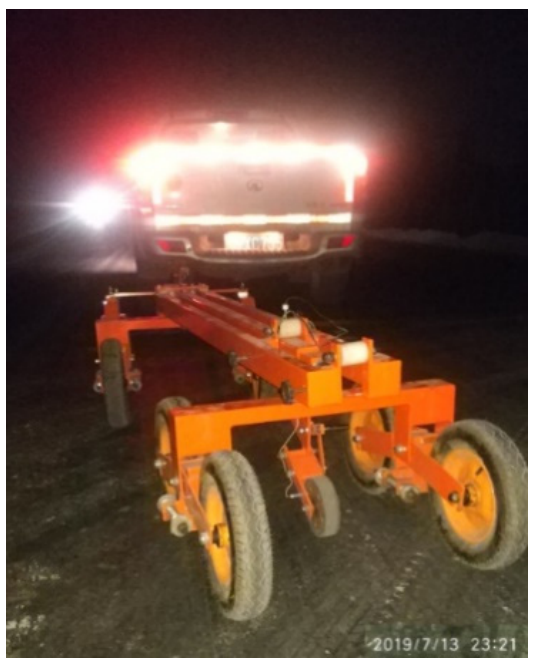

(a)

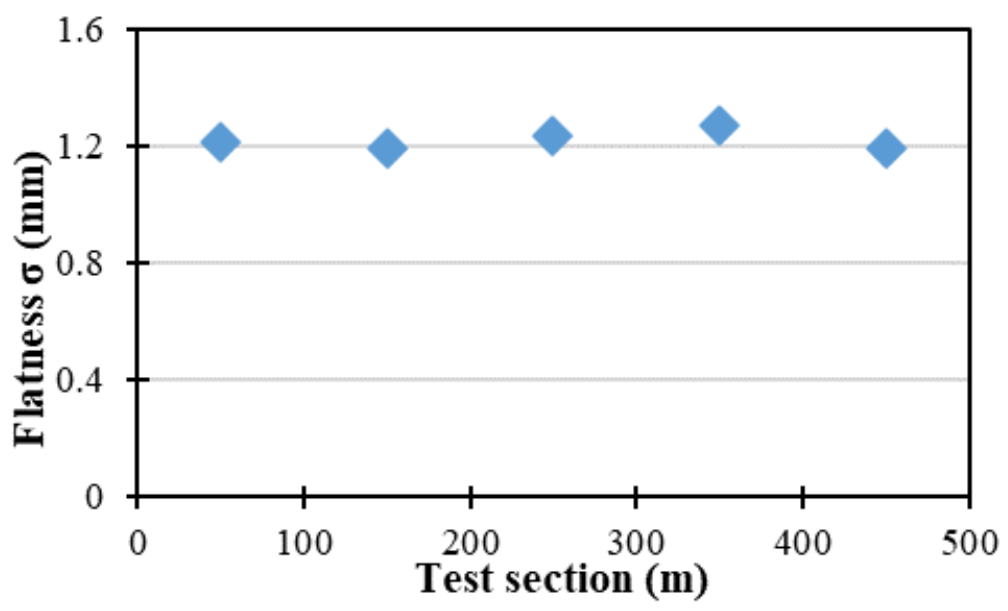

(b)

Figure 7. Flatness test device (a) and measurement results (b) for the base layer containing steel slag aggregates.

\subsubsection{Hydraulically Bound Mixture Strength}

The compressive strength of the hydraulically bound mixture containing steel slag was evaluated with 26 cylindrical samples, which were randomly divided into two groups 
(A and B). All of the specimens were molded with a diameter and height of $150 \mathrm{~mm}$ using the universal testing machine WE-1000. The samples were stored at room temperature for six days and soaked for one day. Eventually, the unconfined compressive strength was assessed using the universal testing machine WE-300B according to the Chinese standard code JTG E51 [36,37]. The compressive strength varied between $8 \mathrm{MPa}$ and $11 \mathrm{MPa}$ as showed in Figure 8 and Table 6.

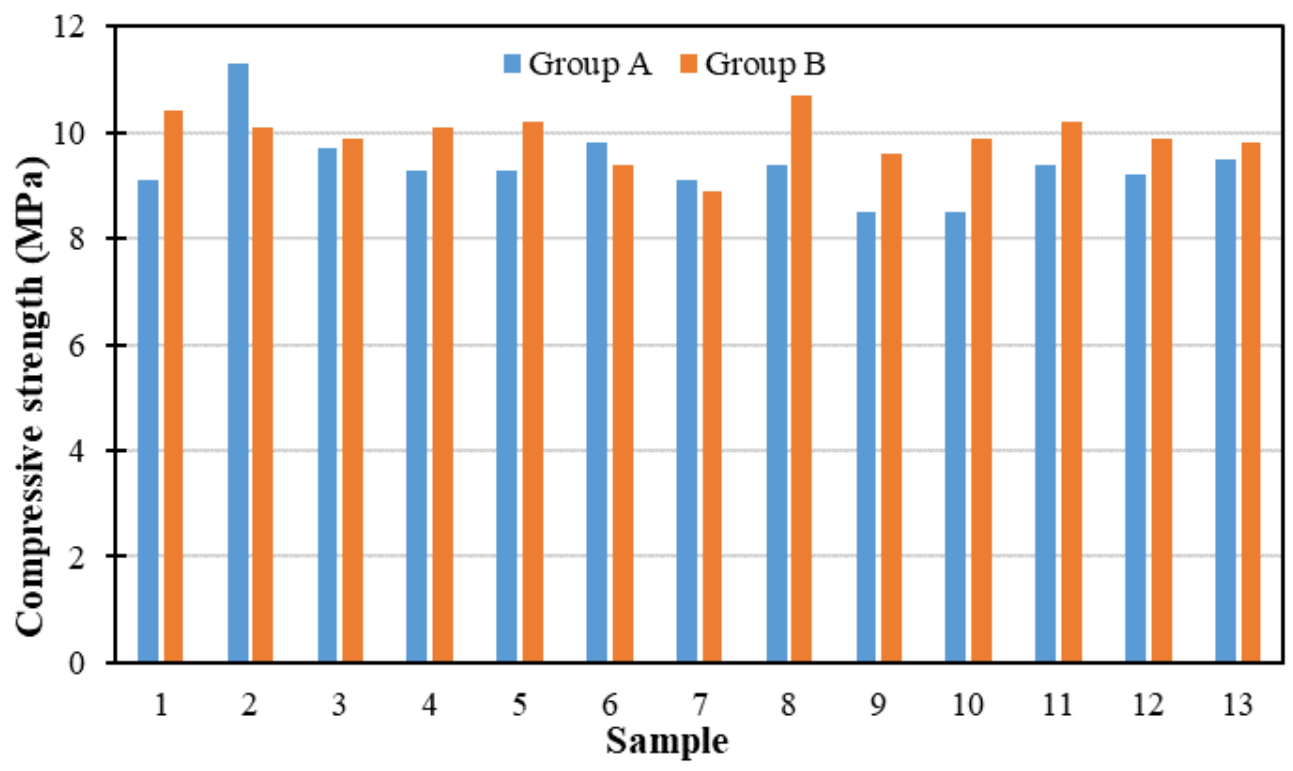

Figure 8. Compressive strengths for sample group A and B.

Table 6. Compressive strength of hydraulically bound mixture containing steel slag.

\begin{tabular}{ccc}
\hline Sample Group & A & B \\
\hline Average strength $(\mathrm{MPa})$ & 9.4 & 9.9 \\
\hline Standard deviation & 0.23 & 0.26 \\
\hline Coefficient of variation $(\%)$ & 2.44 & 2.57 \\
\hline $95 \%$ confidence rate $(\mathrm{MPa})$ & 9.0 & 9.5 \\
\hline
\end{tabular}

The limited variability between the two groups indicated that the compressive strength results were relatively stable. The compressive strength of the two groups of samples was higher than $9 \mathrm{MPa}$ within the $95 \%$ confidence interval. Compared to the natural aggregate mixture (8.0 MPa within the $95 \%$ confidence interval), the steel slag mixture can achieve a higher strength, indicating that steel slag mixture is able to properly resist the compressive stresses generated by road traffic loads [38].

\subsection{Environmental Impacts}

\subsubsection{Energy Consumption}

This study investigated the diesel consumption of the four different roller compactors, and the functional unit was assumed to be the road base layer with a length of $30 \mathrm{~m}$. The assessment of energy consumption and equivalent $\mathrm{CO}_{2}$ emissions referred to the applied compaction procedures ( $\mathrm{C} 1$ for andesite mixture and $\mathrm{C} 3$ for steel slag mixture) previously reported in Section 3.1.1.

Equations (3) and (4) express the energy consumption associated to the vibration process and driving process, respectively. Equation (5) specifies the total energy consumption.

$$
E_{1}=\frac{F \times A \times f \times L \times n \times D}{v \times d},
$$




$$
\begin{gathered}
E_{2}=\frac{P \times D \times L \times n}{v \times d}, \\
E=\frac{E_{1}+E_{2}}{\alpha},
\end{gathered}
$$

where $E_{1}$ is the energy consumption for the vibration process $(\mathrm{kJ}), F$ represents the vibration force $(\mathrm{kN}), A$ is the vibration amplitude $(\mathrm{mm}), f$ indicates the vibration frequency $(\mathrm{Hz})$, $L$ is the working length in one cycle $(\mathrm{m}), n$ represents the number of compactors, $D$ is the working width of the base layer $(\mathrm{m}), v$ indicates the driving speed $(\mathrm{m} / \mathrm{s})$ and $d$ is the compacting width (m). $E_{2}$ is the energy consumption for driving process $(\mathrm{kJ})$ and $P$ is the operation power $(\mathrm{kW})$. E represents the total energy consumption during compaction $(\mathrm{kJ})$ and $\alpha$ is the energy utilization rate of diesel compactors (\%).

Two types of SSWRs were adopted for compaction, namely KS225HD-2 (SSWR-1) and CLG 620H (SSWR-2). SSWRs consume a different amount of diesel when they operate according to strong (S) or weak (W) vibration mode (Table 7): the fuel consumption was calculated based on the number of SSWRs and the working time. The compacting width for DSWR and PTR was $2.1 \mathrm{~m}$ and $2.7 \mathrm{~m}$, respectively. Based on past work [39,40], the average thermodynamic efficiency $\alpha$ for diesel consumption was assumed to be $40 \%$.

Table 7. Compactor parameters according to strong (S) and weak (W) vibration modes.

\begin{tabular}{lcccccc}
\hline \multicolumn{2}{c}{ Compactor } & $\begin{array}{c}\text { Force } \\
\mathbf{( k N )}\end{array}$ & $\begin{array}{c}\text { Frequency } \\
\mathbf{( H z )}\end{array}$ & $\begin{array}{c}\text { Amplitude } \\
\mathbf{( m m )}\end{array}$ & $\begin{array}{c}\text { Width } \\
\mathbf{( m )}\end{array}$ & $\begin{array}{c}\text { Speed } \\
(\mathbf{m} / \mathbf{s})\end{array}$ \\
\hline \multirow{2}{*}{ SSWR-1 } & $\mathrm{S}$ & 412 & 32 & 1.98 & 1.5 & 2 \\
& $\mathrm{~W}$ & 285 & 28 & 0.99 & 1.5 & 2 \\
\hline \multirow{2}{*}{ SSWR-2 } & $\mathrm{S}$ & 400 & 32 & 1.90 & 2.1 & 2 \\
& $\mathrm{~W}$ & 210 & 28 & 1.00 & 2.1 & 2 \\
\hline
\end{tabular}

Figure 9 reports that the total energy consumption for the compaction of the functional unit containing steel slag aggregate or andesite aggregate is $364.27 \mathrm{MJ}$ or $251.99 \mathrm{MJ}$, respectively. Considering the base layer containing natural aggregate, the highest energy amount was consumed by SSWR-1 (107.78 MJ); regarding the hydraulically bound mixture containing Lucheng steel slag, the PTR entailed the biggest energy consumption (140 MJ) because the vibration period of the SSWR was shortened and the static pressure of the PTR was increased.

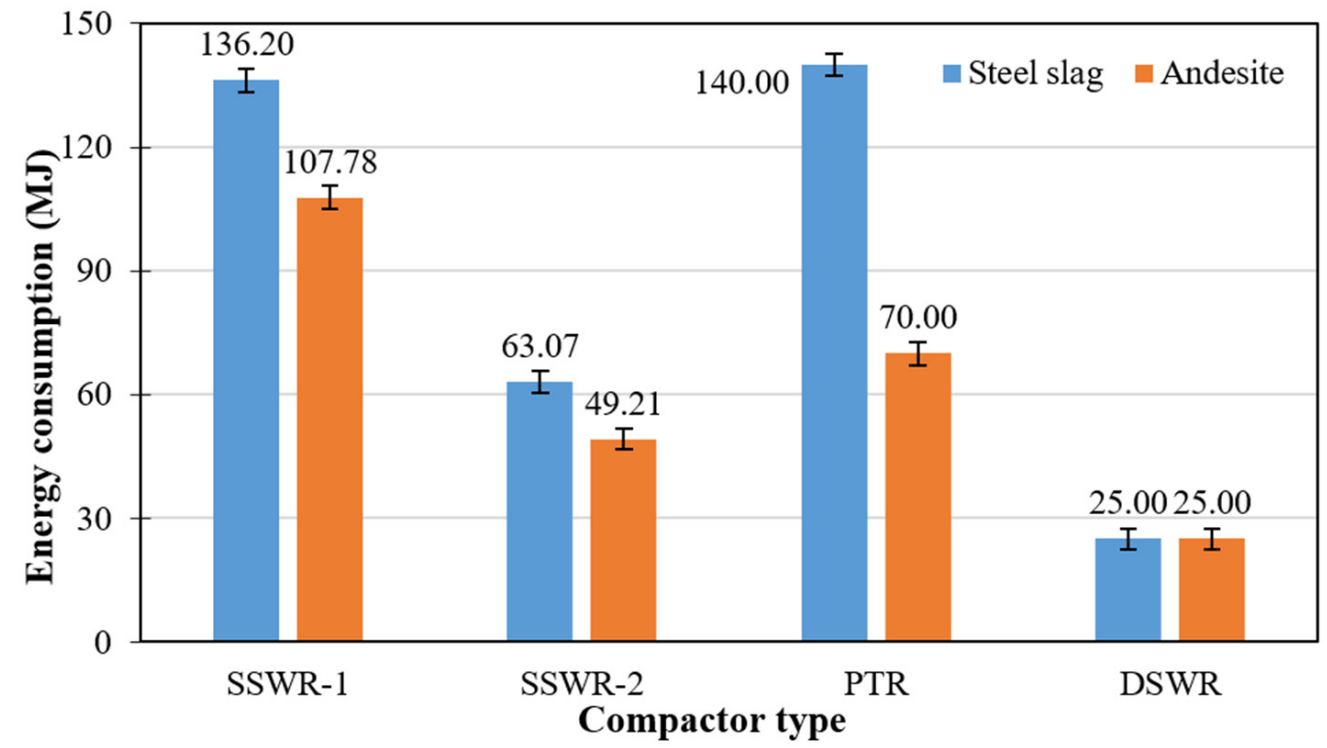

Figure 9. Energy consumption for the compactors used in the investigation. 
On one hand, the use of steel slag as a manufactured aggregate in pavement construction is beneficial given the increasing shortage of natural aggregates; on the other hand, the compaction on site would require more energy than the amount demanded for a traditional base layer to ensure appropriate density and surface flatness. Compared to the compaction of the andesite base course, the application of steel slag generated an additional $2.67 \mathrm{MJ} / \mathrm{m}^{3}$ energy consumption.

\subsubsection{Equivalent $\mathrm{CO}_{2}$ Emission}

This study referred to the China Statistical Yearbook [41] and the Chinese Life Cycle Database (CLCD) [42] to retrieve data related to the diesel supplied during compaction. The equivalent $\mathrm{CO}_{2}$ emission was calculated with Equation (6).

$$
G=\frac{E \times G_{0}}{E_{0}}
$$

where $G$ indicates the equivalent $\mathrm{CO}_{2}$ emission $(\mathrm{kg}), E$ represents the total energy consumption during compaction $(\mathrm{kJ}), G_{0}$ is the standard diesel emission factor $(\mathrm{kg} / \mathrm{kg})$ and $E_{0}$ is the standard diesel calorific rate $(\mathrm{MJ} / \mathrm{kg})$.

Figure 10 displays the equivalent $\mathrm{CO}_{2}$ emissions related to the four types of compactors. Overall, the compaction of the functional unit containing manufactured aggregates or natural aggregates engendered the release of $27.08 \mathrm{~kg}$ and $18.73 \mathrm{~kg}$ equivalent $\mathrm{CO}_{2}$, respectively. Moreover, the PTR generated the largest quantity of equivalent $\mathrm{CO}_{2}$ for steel slag mixture $(10.41 \mathrm{~kg})$, while the SSWR-1 was the major GHG contributor for andesite mixture $(8.01 \mathrm{~kg})$. In our investigated case, compacting steel slag mixture caused higher equivalent $\mathrm{CO}_{2}$ emissions than andesite mixture by $0.20 \mathrm{~kg} / \mathrm{m}^{3}$.

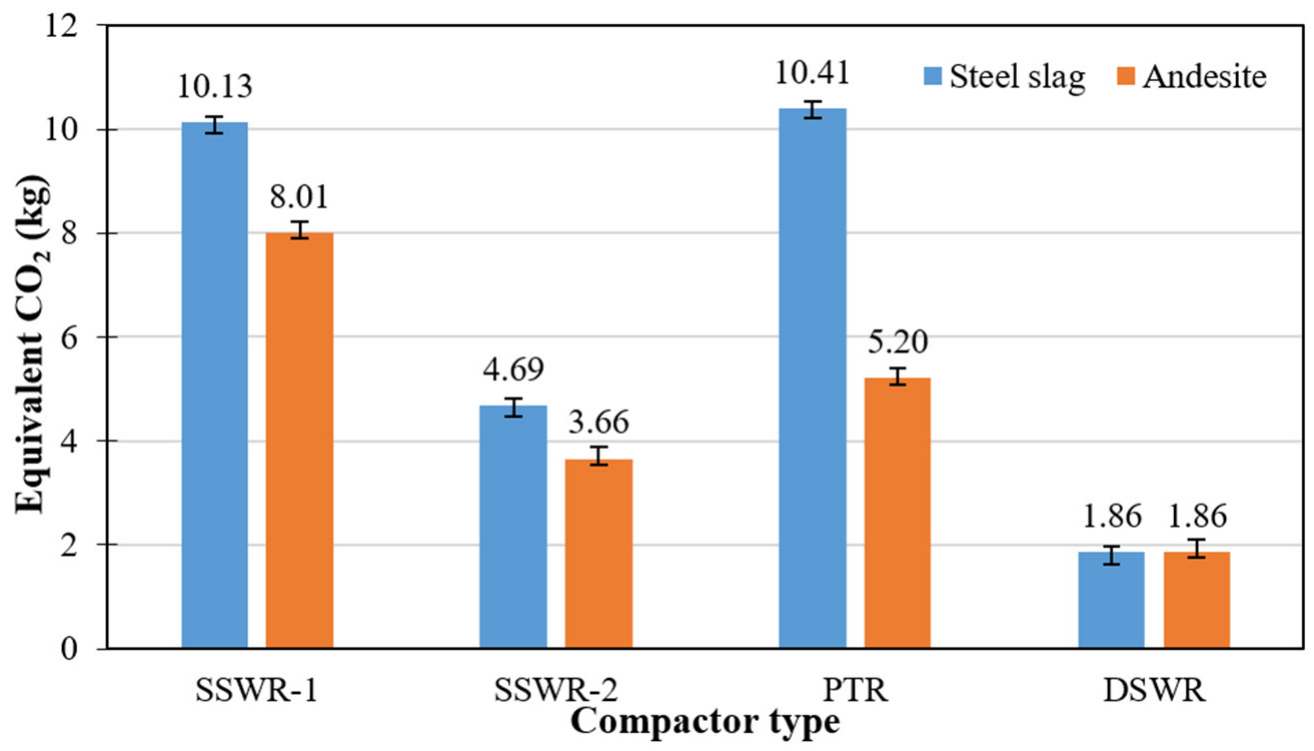

Figure 10. Equivalent $\mathrm{CO}_{2}$ emissions for the compactors used in the investigation.

According to the elaborated results in Figures 9 and 10, steel slag and andesite mixtures presented the same ratio distribution of energy consumption and GHG emissions. To assess the influence of the four compactors, their occupied percentages of GHG emission are illustrated in Figures 11 and 12 for steel slag and andesite base layers, respectively. SSWRs played a significative role in the compaction of steel slag (55\%) and andesite (62\%) mixtures, followed by PTRs and DSWRs; the PTR had undertaken a higher proportion of work in steel slag mixture, by $10 \%$, because its static pressure alleviated the "hard-to-hard" effect. Furthermore, compactor's driving operation accounts for most of the diesel consumption. 


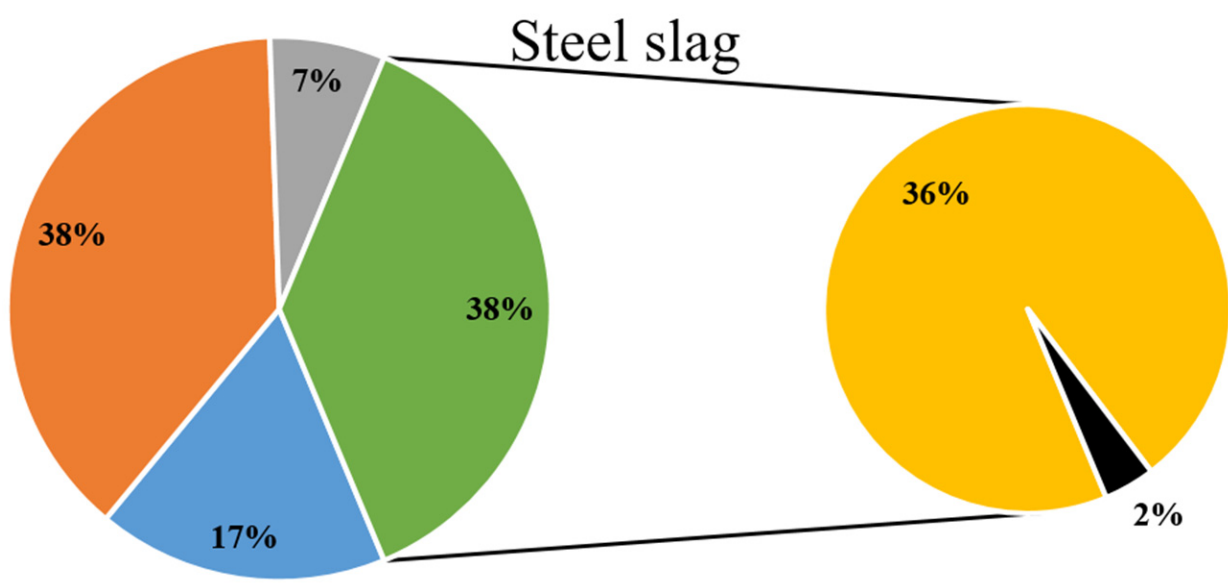

- SSWR-2 $\quad$ PTR $\quad$ DSWR $\quad$ SSWR-1 drive - SSWR-1 vibration

Figure 11. Equivalent $\mathrm{CO}_{2}$ emission composition related to the compaction of the steel slag base layer.

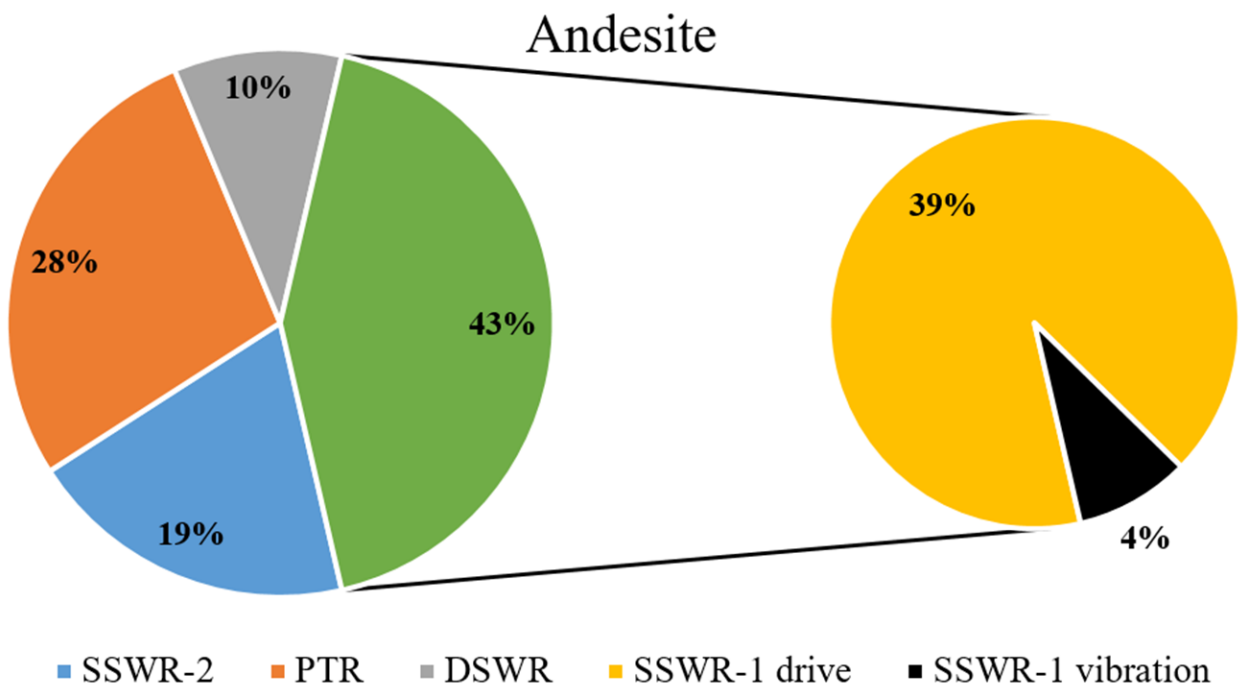

Figure 12. Equivalent $\mathrm{CO}_{2}$ emission composition related to the compaction of the andesite base layer.

From a life cycle perspective, most studies have reported that using manufactured aggregates such as steel slag in lieu of natural aggregates can positively contribute to the reduction of environmental depletion $[43,44]$. However, the calculated results obtained from this investigated case show that when only focusing on the environmental impacts in compaction procedures, steel slag aggregates cause higher energy consumption and GHG emissions than andesite. Hence, reducing the environmental impacts of compaction can distinctly strengthen the road sustainability by employing manufactured aggregates instead of natural aggregates.

\section{Conclusions}

Steel slag is a solid waste which can be conveniently recycled in civil engineering applications. This study characterized the use of steel slag in a hydraulically bound mixture for road base layers. Furthermore, an additional traditional base layer containing andesite (a natural aggregate) was also investigated for comparison. The compaction procedures of the base layers have been thoroughly investigated in the field by means of four different compactors; furthermore, surface flatness, layer density and the compressive strength of the hydraulically bound mixture were also evaluated. Eventually, the environmental impacts of the compaction operations were assessed. 
Based on the performed analyses, results, and discussion, the following conclusions can be drawn:

(1) Steel slag aggregate offers better roughness and surface micro-morphology properties than andesite aggregate in this investigated case.

(2) The base layer containing steel slag aggregate fulfils the road construction requirements specified by the standard code, namely compactness, surface flatness and compressive strength of the hydraulically bound mixture.

(3) Strong vibrations should be avoided or reduced during compaction to mitigate the adverse "hard-to-hard" effect between adjacent steel slag particles; the static pressure exerted by the rolling compactors should be increased.

(4) Compared to the andesite base course, the base layer containing steel slag entails a higher diesel consumption used by the compactors: an additional $2.67 \mathrm{MJ} / \mathrm{m}^{3}$ of energy and $0.20 \mathrm{~kg} / \mathrm{m}^{3}$ equivalent $\mathrm{CO}_{2}$ emissions were generated.

Author Contributions: B.G.: Conceptualization, Formal analysis, Investigation; C.Y.: Conceptualization, Investigation, Writing—Original Draft; Y.Z.: Methodology, Writing-Review \& Editing, Investigation; F.W.: Methodology, Writing—Review \& Editing, Supervision; X.Z.: Writing-Review \& Editing, Resources, Visualization; D.M.B.: Writing—Review \& Editing, Visualization, Supervision; S.W.: Methodology, Supervision, Project administration. All authors have read and agreed to the published version of the manuscript.

Funding: This research was funded by the National Natural Science Foundation of China (No. 71961137010 and No. 51778515), the Ministry of Science and Technology National Key R\&D Plan (No. 2017YFE0111600) and the State Key Laboratory of Silicate Materials for Architectures (Wuhan University of Technology, No. SYSJJ2019-20). Finally, this study was supported by the Technological Innovation Major Project of Hubei Province (2019AEE023).

Institutional Review Board Statement: Not applicable.

Informed Consent Statement: Informed consent was obtained from all subjects involved in the study.

Data Availability Statement: Some or all data, models, or code generated or used during the study.

Conflicts of Interest: The authors declare no conflict of interest.

\section{References}

1. U.S. Department of Transportation. Highway Finance Data Collection. Our Nation's Highways: 2011; Federal Highway Administration: Washington, DC, USA, 2014.

2. Improving America's Transportation Infrastructure: The Road Forward; U.S. Department of Transportation: Washington, DC, USA, 2017.

3. Development Statistics Bulletin of Transportation Industry in 2018; Ministry of Transport of China: Beijing, China, 2019.

4. Statistical Bulletin of Transportation Industry Development in 2019; Ministry of Transport of China: Beijing, China, 2020.

5. Laurance, W.F.; Clements, G.R.; Sloan, S.; O'Connell, C.S.; Mueller, N.D.; Goosem, M.; Venter, O.; Edwards, D.P.; Phalan, B.; Balmford, A.; et al. A global strategy for road building. Nat. Cell Biol. 2014, 513, 229-232. [CrossRef]

6. Gao, D.; Wang, F.-P.; Wang, Y.-T.; Zeng, Y.-N. Sustainable utilization of steel slag from traditional industry and agriculture to catalysis. Sustainability 2020, 12, 9295. [CrossRef]

7. Skaf, M.; Manso, J.M.; Aragón, Á.; Fuente-Alonso, J.A.; Ortega-López, V. EAF slag in asphalt mixes: A brief review of its possible re-use. Resour. Conserv. Recycl. 2017, 120, 176-185. [CrossRef]

8. Guo, J.; Bao, Y.; Wang, M. Steel slag in China: Treatment, recycling, and management. Waste Manag. 2018, 78, 318-330. [CrossRef]

9. Yi, H.; Xu, G.; Cheng, H.; Wang, J.; Wan, Y.; Chen, H. An overview of utilization of steel slag. Procedia Environ. Sci. 2012, 16, 791-801. [CrossRef]

10. Horii, K.; Kato, T.; Sugahara, K.; Tsutsumi, N.; Kitano, Y. Overview of iron/steel slag application and development of new utilization technologies. Nippon Steel Sumitomo Tech. Rep. 2015, 109, 5-11.

11. Jullien, A.; Proust, C.; Martaud, T.; Rayssac, E.; Ropert, C. Variability in the environmental impacts of aggregate production. Resour. Conserv. Recycl. 2012, 62, 1-13. [CrossRef]

12. Barišić, I.; Grubeša, I.N.; Kutuzović, B.H. Multidisciplinary approach to the environmental impact of steel slag reused in road construction. Road Mater. Pavement Des. 2017, 18, 897-912. [CrossRef]

13. Moustakas, K.; Mavropoulos, A.; Katsou, E.; Haralambous, K.-J.; Loizidou, M. Leaching properties of slag generated by a gasification/vitrification unit: The role of $\mathrm{pH}$, particle size, contact time and cooling method used. J. Hazard. Mater. 2012, 207-208, 44-50. [CrossRef] [PubMed] 
14. Chand, S.; Paul, B.; Kumar, M. Short-term leaching study of heavy metals from LD slag of important steel industries in Eastern India. J. Mater. Cycles Waste Manag. 2016, 19, 851-862. [CrossRef]

15. Xie, J.; Wu, S.; Zhang, L.; Xiao, Y.; Ding, W. Evaluation the deleterious potential and heating characteristics of basic oxygen furnace slag based on laboratory and in-place investigation during large-scale reutilization. J. Clean. Prod. 2016, 133, 78-87. [CrossRef]

16. Euroslag \& Eurofer. Position Paper on the Status of Ferrous Slag complying with the Waste Framework Directive (Articles 5/6) and the REACH Regulation; European Slag Association: Duisburg, Germany, 2012.

17. Monshi, A.; Asgarani, M.K. Producing Portland cement from iron and steel slags and limestone. Cem. Concr. Res. 1999, 29, 1373-1377. [CrossRef]

18. Maslehuddin, M.; Sharif, A.M.; Shameem, M.; Ibrahim, M.; Barry, M. Comparison of properties of steel slag and crushed limestone aggregate concretes. Constr. Build. Mater. 2003, 17, 105-112. [CrossRef]

19. Reddy, A.S.; Pradhan, R.; Chandra, S. Utilization of Basic Oxygen Furnace (BOF) slag in the production of a hydraulic cement binder. Int. J. Miner. Process. 2006, 79, 98-105. [CrossRef]

20. Altun, I.A.; Yilmaz, I. Study on steel furnace slags with high $\mathrm{MgO}$ as additive in Portland cement. Cem. Concr. Res. 2002, 32, 1247-1249. [CrossRef]

21. Lee, K.-M.; Park, P.-J. Estimation of the environmental credit for the recycling of granulated blast furnace slag based on LCA. Resour. Conserv. Recycl. 2005, 44, 139-151. [CrossRef]

22. Saade, M.R.M.; da Silva, M.G.; Gomes, V. Appropriateness of environmental impact distribution methods to model blast furnace slag recycling in cement making. Resour. Conserv. Recycl. 2015, 99, 40-47. [CrossRef]

23. Pasetto, M.; Pasquini, E.; Giacomello, G.; Baliello, A. Life-cycle assessment of road pavements containing marginal materials: Comparative analysis based on a real case study. In Pavement Life-Cycle Assessment; CRC Press: London, UK, 2017.

24. Václavík, V.; Ondová, M.; Dvorský, T.; Eštoková, A.; Fabiánová, M.; Gola, L. Sustainability potential evaluation of concrete with steel slag aggregates by the LCA method. Sustainability 2020, 12, 9873. [CrossRef]

25. Anastasiou, E.; Liapis, A.; Papayianni, I. Comparative life cycle assessment of concrete road pavements using industrial by-products as alternative materials. Resour. Conserv. Recycl. 2015, 101, 1-8. [CrossRef]

26. Wang, F.; Hoff, I.; Yang, F.; Wu, S.; Xie, J.; Li, N.; Zhang, L. Comparative assessments for environmental impacts from three advanced asphalt pavement construction cases. J. Clean. Prod. 2021, 297, 126659. [CrossRef]

27. Ministry of Transport of China. Test Methods of Aggregate for Highway Engineering (JTG E42-2005); China Communications Press: Beijing, China, 2005.

28. Kandhal, P.S.; Hoffman, G.L. Evaluation of steel slag fine aggregate in hot-mix asphalt mixtures. Transp. Res. Rec. J. Transp. Res. Board 1997, 1583, 28-36. [CrossRef]

29. Frías, M.; De Rojas, M.S.; Uría, A. Study of the instability of black slags from electric arc furnace steel industry. Mater. Constr. 2002, 52, 79-83. [CrossRef]

30. Wang, Q.; Wang, D.; Zhuang, S. The soundness of steel slag with different free $\mathrm{CaO}$ and $\mathrm{MgO}$ contents. Constr. Build. Mater. 2017, 151, 138-146. [CrossRef]

31. Nallathambi, P.; Karihaloo, B.L.; Heaton, B.S. Effect of specimen and crack sizes, water/cement ratio and coarse aggregate texture upon fracture toughness of concrete. Mag. Concr. Res. 1984, 36, 227-236. [CrossRef]

32. Xiao, Y.; Wang, F.; Cui, P.; Lei, L.; Lin, J.; Yi, M. Evaluation of fine aggregate morphology by image method and its effect on skid-resistance of micro-surfacing. Materials 2018, 11, 920. [CrossRef] [PubMed]

33. Cui, P.; Xiao, Y.; Yan, B.; Li, M.; Wu, S. Morphological characteristics of aggregates and their influence on the performance of asphalt mixture. Constr. Build. Mater. 2018, 186, 303-312. [CrossRef]

34. Ministry of Transport of China. Code for Field Test of Highway Subgrade and Pavement (JTGE 60-2008); China Communications Press: Beijing, China, 2008.

35. Winter, M. The Determination of the Acceptability of Selected Fragmenting Materials for Earthworks Compaction: Prepared for National Roads Directorate, Scottish Office Development Department; Thomas Telford: Lomdon, UK, 1999.

36. Shen, J.; Li, F.; Lv, G. JTJ059-95 Highway Subgrade Pavement Field Test Procedures; People's Communications Press: Beijing, China, 1995.

37. Ministry of Transport of China. Test Methods of Materials Stabilized with Inorganic Binders for Highway Engineering (JTG E51-2009); China Communications Press: Beijing, China, 2009.

38. Huang, Y.H. Pavement Analysis and Design; Pearson: London, UK, 2004.

39. Edwards, C.F.; Teh, K.-Y.; Miller, S.L. Low exergy loss chemical engines. In Global Climate E Energy Project; Stanford University: Stanford, CA, USA, 2006.

40. Tebbe, P. DIESEL ENGINE. 2015. Available online: https://cset.mnsu.edu/engagethermo/components_diesel.html (accessed on 1 January 2021).

41. China Statistical Yearbook; National Bureau of Statistics of China: Beijing, China, 2012. 
42. Chinese Life Cycle Database; IKE Environmental Technology Sichuan University: Chengdu, China, 2012.

43. Leal, D.; Winter, M.G.; Seddon, R.; Nettleton, I.M. A comparative life cycle assessment of innovative highway slope repair techniques. Transp. Geotech. 2020, 22, 100322. [CrossRef]

44. Gomes Correia, A.; Winter, M.G.; Puppala, A.J. A review of sustainable approaches in transport infrastructure geotechnics. Transp. Geotech. 2016, 7, 21-28. [CrossRef] 